Pesq. Vet. Bras. 29(11):931-937, novembro 2009

\title{
Health management practices and disease prevalence in dairy sheep systems in Argentina ${ }^{1}$
}

\author{
Victor H. Suárez ${ }^{2^{*}}$ and Margarita R. Busetti²
}

\begin{abstract}
Suárez V.H. \& Busetti M.R. 2009. Health management practices and disease prevalence in dairy sheep systems in Argentina. Pesquisa Veterinária Brasileira 29(11):931-937. Estación Experimental Agropecuaria de Anguil, INTA, CC 11, 6326 Anguil, La Pampa, Argentina. E-mail: vsuarez@anguil.inta.gov.ar

A cross-sectional survey of 19 dairy sheep farms in Argentina was carried out with the purpose to know farm management, health practices, and occurrence and mortality of diseases. The survey comprised $40 \%$ of all sheep milking farms in Argentina. A questionnaire was conducted by way of personal interviews with sheep owners during farm visits. The proportions of farms reporting routine vaccination for clostridial diseases, contagious ecthyma, pneumonia and mineral and vitamin parenteral administration were $63 \%, 47.3 \%$, $16.6 \%$ and $42.1 \%$ respectively. Regular treatment against lice was used in $37.5 \%$ of the farms, and $89.5 \%$ o the farmers treated against gastrointestinal nematodes (GIN). The mean number of GIN drenches per farm was $2.26 \pm 1.78$ annually. In $68.4 \%$ of the milking flocks the California Mastitis Test was regularly done and $55.6 \%$ of the farmer managers had sampled their flocks once a year for Brucella ovis antibodies. During the pre-mating period respectively $68.4 \%$ and $50 \%$ of farmers clinically examined their rams and ewe for general health and teeth condition. The udders of ewes were frequently inspected at the start of each milking period. The most important parasite problems noticed were GIN (reported by $57.9 \%$ of farmers), lice $(57.9 \%)$ and scabies (10.5\%) and the most frequent infectious diseases were ecthyma $(73.7 \%)$, pneumonia and other respiratory problems (57.9\%), clinical mastitis (55.6\%), clostridial diseases $(36.9 \%)$ and foot lameness $(35.2 \%)$. Photosensitivity (47.4\%) and ruminal acidosis (42.1\%) were reported as other frequent toxic or metabolic disorders. Owners mentioned that the mean lifespan or milk productive time per ewe was $4.5 \pm 1.4$ years. Perinatal lamb mortality was $8.5 \%$ and the total flock mortality rates, above the first $24 \mathrm{~h}$ of life was $6.9 \%$. The high rates of lamb mortality during the pre-weaning $(10.3 \%)$ and post-weaning $(5.9 \%)$ periods indicate that this problem, as well as the most prevalent diseases, should be the subject of further studies.
\end{abstract}

INDEX TERMS: Dairy sheep, survey, health management, disease prevalence, Argentina.

RESUMO.- [Práticas de manejo sanitário e frequência de doenças em ovinos leiteiros na Argentina.] Foi realizado um levantamento longitudinal em 19 fazendas de ovinos leiteiros na Argentina com o objetivo de conhecer práticas de manejo, medidas sanitárias e ocorrência e freqüência das enfermidades. O levantamento incluiu $40 \%$ de todas as fazendas do país que produzem leite ovino. Um questionário foi utilizado com entrevistas pessoais com

\footnotetext{
${ }^{1}$ Received on April 15, 2009.

Accepted for publication on July 29, 2009.

2 Estación Experimental Agropecuaria de Anguil, INTA, CC 11, 6326 Anguil, La Pampa, Argentina. *Corresponding author: vsuarez@ anguil.inta.gov.ar
}

os ovinocultores durante visita às fazendas. A percentagem de fazendas que relataram vacinação rotineira contra clostridioses, ectima contagioso, pneumonia e administração parenteral de minerais e vitaminas foi $63 \%$, $47,3 \%, 16,6 \%$ e $42,1 \%$, respectivamente. Parte dos produtores $(37,5 \%)$ realizava tratamento regularmente contra piolhos e $89,5 \%$ contra nematódeos gastrintestinais. O número médio de tratamentos anti-helmínticos anuais, por fazenda, era de 2,26+1,78. Em 68,4\% dos rebanhos leiteiros o Califórnia Mastite Teste (CMT) era regularmente realizado e $55,6 \%$ dos produtores colhiam amostras de seus rebanhos uma vez por ano para diagnóstico de $\mathrm{Bru}$ cella ovis. Durante o período de pré-acasalamento $68,4 \%$ 
e $50 \%$ dos produtores examinavam clinicamente seus carneiros e a condição geral e de dentes de suas oveIhas. O úbere das ovelhas era geralmente inspecionado no início da ordenha. Os principais problemas parasitários eram nematódeos gastrintestinais (mencionado por $57,9 \%$ dos produtores), piolhos $(57,9 \%)$ e sarna $(10,5 \%)$ e as doenças infecciosas mais frequentes foram ectima contagioso $(73,7 \%)$, pneumonia e outros problemas respiratórios $(57,9 \%)$, mastite clínica $(55,6 \%)$, clostridioses $(36,9 \%)$ e laminite $(35,2 \%)$. Fotossensibilização $(47,4 \%)$ e acidose ruminal $(42,1 \%)$ foram relatadas como as principais desordens tóxicas ou metabólicas. Na visão dos produtores, a expectativa de vida produtiva ou o tempo de produção de leite por ovelha era de $4,5+1,4$ anos. A mortalidade perinatal foi de $8,5 \%$ e a taxa de mortalidade total do rebanho, depois das primeiras 24 horas de vida, foi de $6,9 \%$. As altas taxas de mortalidade de cordeiros durante os períodos de pré-desmame (10,3\%) e pós-desmame $(5,9 \%)$ indicam que isto, assim como as doenças mais prevalentes, deve ser tema de mais estudos.

TERMOS DE INDEXAÇÃO: Ovinos leiteiros, levantamento, manejo sanitário, prevalência de doenças, Argentina.

\section{INTRODUCTION}

In the central Pampeana Region of Argentina, small farmer agriculture, characterized by mixed systems of crops and livestock, has decreased as a result of economic transformations prevailing in Argentina, compounded by frequent changes in international grain prices. Net returns from traditional exportable animal products, such as cattle meat or milk, have decreased significantly because of internal political measures, with the result that small- and medium-sized farms have become less profitable. As a consequence, in the Pampeana Region large marginal areas have been transformed into intensive livestock or arable crop production lands. In this scenario, these small or medium sized enterprises strive to increase economic efficiency by means of intensive grazing, renting their lands to grain crop production or diversify their products to compensate for depressed meat prices or high input costs. Sheep play an important economic role in the overall production system of these farms, where most sheep production is for wool and meat. For these farmers a good alternative to increase cash inputs is to produce milk and cheese from both milk and meat purpose breeds.

In Argentina as in the United States and Canada (Thomas 2004), dairy sheep breeding mainly for cheese production is an alternative enterprise for small to mediumsize farms (Suárez 2004). A recent census (Busetti \& Suárez, unpublished) indicated the there were only 48 dairy sheep farms in Argentina. The most common milk sheep breeds being recently adapted to Argentina regional systems are East Friesian and Pampinta (3/4 East Friesian X $1 / 4$ Corriedale) (Suárez et al. 1998) and efficient husbandry and strategies are yet to be studied and developed. In particular dairy sheep health status and health management practices need to be investigated, as indicated by frequent owner inquiries and private veterinarian consultations. This information is essential to safeguard this new activity concerning the quality of theirs products, to prevent potential zoonotic diseases, and to support further decision-making for development projects (Thrusfield 1997).

A descriptive survey was conducted in order to document and describe current farm management health practices and disease occurrence over the previous two years. This included details and frequency of health management and treatment activities, ovine health problems, and counts of the numbers of sheep that died, stratified by stock class.

\section{MATERIALS AND METHODS}

\section{Survey sampling}

A cross-sectional survey was carried out during 2007 in 19 dairy sheep farms in the following provinces of Argentina: Buenos Aires $(n=12)$, La Pampa $(n=4)$, Santa Fe $(n=1)$, San Juan $(n=$ 1) and Mendoza $(n=1)$. Health management and treatments currently utilized, counts of the number of sheep that died stratified by stock class in the last year, and the occurrence of dairy sheep health problems over the previous two years were recorded. Even though small in number, these 19 farms represent $40 \%$ of all dairy sheep farms in Argentina, and $54.8 \%$ of those in the Pampeana Region of the country. Eleven farms were in the humid East of the Pampeana Region, the other eight were in the semiarid western region, including the semiarid Pampeana Region $(n=6)$ and the Cuyo Region $(n=2)$.

\section{Dairy sheep management characteristics}

The majority of sheep dairy systems consist of grazing annual and perennial pastures, supplemented with grain (corn, sorghum, oat) and hay as a source of feed. Lambing takes place during the early spring (August) and in $70.6 \%$ of the flocks the ewes are machine milked commencing from 15 to 20 days post-partum; ewes are separated from their lambs in the evening and milked once daily early in the morning, whereupon their lambs are allowed to suckle for $7 \mathrm{~h}$ during the day. Lambs are weaned around 45 to 90 days after birth and male lambs are marketed at $25-30 \mathrm{~kg}$ of live-weight. Thereafter, ewes are exclusively machine milked either once or twice daily. The most frequent shearing time is during the spring (October-November), with only two farm managers shearing before lambing. East Friesian and Pampinta breeds and their crosses (mostly with Corriedale and Romney Marsh breeds) were the most common breeds.

\section{Questionnaire survey}

A questionnaire with a checklist of 125 guideline questions was undertaken by way of personal interviews with sheep holders during a farm visit. Mostly open questions were used, but a farm manager's opinion was also sought for many questions on their evaluation of the importance of health problems. In addition the questionnaire included general farm descriptors, such as animal breeds, details of breeding and feed management, flock sizes and farm dairy facilities and structures.

The questions concerned health plan, veterinary consultation, health management practices and treatments, as well as the numbers and classes of sheep that died throughout the year (July 
to July) before the interviews. Farmers were questioned on the occurrence of a list of 49 health problems that occurred during the previous two years. Only those diseases that were diagnosed by a veterinarian and those that were easy to recognize from the farm manager's description were included. This schedule of health problems included morbidity, mortality, animal classes involved, clinical symptoms, time of the year and treatments.

\section{Data analysis}

Data were checked at several levels for errors and ambiguous responses. In many cases, the veterinarians involved were interviewed by telephone to clarify doubts of a diagnosis in question. Descriptive statistics were calculated for each variable, including prevalence and counts of the total numbers of pathological cases (Thrusfield 1997, Wayne et al. 1987). Results were expressed as period prevalence (number of cases identified during the previous 2 years, divided by the number of farms interviewed) estimates at both the farm and individual animal level. Data were stratified by region, with farms in the humid East and those in the semiarid West analyzed separately. Results are presented mainly in the form of descriptive tabular summaries. Chi-square $(\div 2)$ and $F$ tests were applied to the prevalence estimates and continuously distributed responses, respectively. Interpretation of each statistical test was carried out at an alpha level of 0.05 .

\section{RESULTS}

The mean number of hectares for dairy sheep and the mean number of sheep per farm were $20.8 \pm 22$ ha and $164.8 \pm 158$ sheep, respectively. The mean density was $12.2 \pm 12$ sheep/ha. The mean flock management practices involved a Feb-Apr mating, Jul-Sep lambing with ewes milked once $(84 \%)$ or twice $(16 \%)$ a day for 5-7 months. Sheep were the only production animals present on $42.1 \%$ of farms, but $36.8 \%$ also raised cattle, $10.5 \%$ raised goats and $36.8 \%$ raised pigs.

\section{Health management practices and treatments}

The majority of owners (63.1\%) had a health control plan for the flock and $66.7 \%$ had a veterinary advisor that visited the farm every 30 to 50 days periods. The most frequent routine practices, vaccinations and treatments are summarized in Table 1.

Table 1. Veterinary and health management practices in dairy milk sheep farms in Argentina

\begin{tabular}{lc}
\hline Health management practices & $(\%)$ \\
\hline Triple vaccine a & 78.9 \\
Contagious ecthyma vaccine & 47.3 \\
Pneumonia vaccine & 16.6 \\
Lice treatment & 37.5 \\
Bot fly treatment & 70.0 \\
Anthelmintic treatment & 89.5 \\
California Mastitis Test & 68.4 \\
Intramammary dry treatments & 26.3 \\
Brucella ovis test & 55.6 \\
Ram clinic examination & 68.4 \\
Ewe condition examination & 50.0 \\
Ewe lamb tail docking & 50.0 \\
\hline
\end{tabular}

a Triple vaccine (enterotoxaemia, blackleg and gas gangrene).
A triple vaccine against enterotoxaemia, blackleg and gas gangrene was used once, twice or more frequently in a year, by $33.3 \%, 53.3 \%$ and $13.3 \%$ of farmer managers, respectively. The more frequent periods for vaccination $(40 \%)$ were pre-mating and pre-partum.

Generally contagious ecthyma vaccine was applied to lambs between birth and one month of age. Only one farm utilized anthrax vaccine.

Mineral and vitamin commercial products were administered annually by $42.1 \%$ of farmers, mostly in replacement and pre-partum ewes and any thin or emaciated sheep.

To control ectoparasites, $37.5 \%$ of farm managers treated their stock for lice twice with 15 days interval with pour-on pyrethroids. Likewise, they treated for screwworm myiasis (Cochlyomia hominivorax larvae) mostly with pyrethroids and organophosphate sprays, frequently combined with avermectins or closantel $(80 \%)$. Farm managers treated for Oestrus ovis (bot fly) with closantel $(70 \%)$ or avermectins $(30 \%)$ during the spring or summer, but $88 \%$ of them applied targeted selective treatment by dosing only animals with clinical signs such as nasal discharge and sneezing.

The average number of anthelmintic drenches used per year (mainly on lactating ewes and replacement ewe lambs) was $2.26 \pm 1.78$. The drugs used were: avermectins (34.3\%), benzimidazoles (25.7\%), closantel $(25.7 \%)$ and levamisol (14.3\%). Among the farmers who used anthelmintics, $98.1 \%$ dosed adult sheep, and $91.7 \%$ dosed the youngest age classes. Pre-partum (38.2\%) and premating $(20.6 \%)$ were the more frequent periods for treating ewes. Spring (38.9\%) was the most frequent period for treating lambs. Veterinary advisors are consulted by $71.4 \%$ of the farmers. Farmer managers $(64.7 \%)$ took fecal samples for sporadic worm egg counts diagnosis, but only $25 \%$ of them frequently used worm egg counts for monitoring worm infections along the year. When asked about current anthelmintic efficacy, $16.7 \%$ and $8.3 \%$ asserted that ivermectins and benzimidazoles, respectively, were less effective than previously.

The California Mastitis Test (CMT) was used on a monthly basis by $68.4 \%$ of farmers during the entire lactating period. CMT positive ewes were generally treated with intramammary infusions and systemic antibiotics. Only $26.3 \%$ of farm managers reported that any ewes which had not ceased milk production two month prior to parturition were artificially dried off and infused with dry treatment products.

Either the total flock $(11.4 \%)$ or samples $(44.2 \%)$ of the animals (mostly rams) were collected annually for brucellosis diagnosis (Brucella ovis). In addition $47.4 \%$ of flocks were sampled at least once for other diseases, for instance maedi visna, tuberculosis, and Brucella abortus.

Rams were clinically evaluated by veterinarians $(68.4 \%)$ before mating. The teeth and general conditions of ewes were checked in $50 \%$ of the farms, generally 20 30 days pre-mating. The udders of ewes were inspected 
and eventually cleaned and trimmed, usually when milking commenced. In $76.5 \%$ of the flocks feet were inspected and trimmed at least one per year, generally only when problems arise, but not as routine practice. Only replacement ewe lambs were tail docked in $50 \%$ of the farms. Rubber elastrator rings were used within the first 20 days of age.

\section{Mortality rates}

Table 2 provides details of mortality rates for each class of animal present on farm. The mean perinatal mortality (lamb deaths during parturition or within 48 hours thereafter) was $8.5 \%$. The main perinatal mortality reasons were starvation $(42.2 \%$ of responses), hypothermia $(25.1 \%)$, dystocia $(23.1 \%)$, predation $(8.1 \%)$ and unidentified infections (1.5\%). There was no difference between regions in perinatal mortality.

Table 2. Mean mortality rates in dairy sheep farms in Argentina

\begin{tabular}{lc}
\hline Mortality rates & $(\%)$ \\
\hline Perinatal $^{\mathrm{a}}$ & 8,5 \\
Lambs aged 3-30 days $^{\text {Pre-weaning lambs }}{ }^{\mathrm{b}}$ & 9.6 \\
Post-weaning lambs & 10.3 \\
Milking ewes $^{\text {Adult sheep }}{ }^{\mathrm{c}}$ & 5.9 \\
Entire flock $^{\mathrm{d}}$ & 2.5 \\
\end{tabular}

a Mortality occurred during lambing up to $48 \mathrm{~h}$ of birth.

b Mortality occurred in lambs from $48 \mathrm{~h}$ of birth up to weaning, including those aged 3-30 days.

c Mortality occurred in all adult flock (rams and all ewes).

d Entire flock excludes perinatal mortality.

The total mean flock mortality rates (excluding perinatal mortality) varied from $8.9 \%$ in the eastern region to $4.7 \%$ in the western region, but differences were not significant $(\mathrm{P}<0.22)$. In the same way, mortality rates varied from $4.1 \%$ to $2.4 \%$ east to west in adults, and from $15.5 \%$ to $7.7 \%$ in lambs from more than 48 hours to 1 year old.

\section{Occurrence and frequency of diseases}

Table 3 summarizes the prevalence of parasite diseases. Outbreaks of sheep scab (Psoroptes ovis) were

Table 3. Prevalence of flocks with parasitic diseases in dairy sheep farms in Argentina

\begin{tabular}{lc}
\hline Disease prevalence & $(\%)$ \\
\hline Lice & 57.9 \\
Sheep scab & 10.5 \\
Screwworm & 94.7 \\
Bot fly & 42.1 \\
Gastrointestinal nematodes & 57.9 \\
Lungworms & 5.3 \\
Tapeworms & 31.6 \\
Hydatid cysts & 5.3 \\
Flukes & 5.3 \\
Coccidia & 5.3
\end{tabular}

characterized by mid morbidity and low mortality. Within those flocks with biting lice, $40 \%$ of farm managers reported morbidities above $25 \%$ mostly during the winter and early spring. Only Bovicola ovis (formerly Damalinia ovis) was recovered from sampled flocks.

Neither screwworm (Cochlyomia hominivorax) with a mean flock morbidity rate of $5.5 \pm 5.5 \%$, nor bot fly were regarded as important problems by farmer mangers, although those from the western semiaridarid region $(62.5 \%)$ reported more $(\mathrm{P}<0.001)$ ewes to be affected by bot fly than in the eastern region (18.2\%).

Of the $57.9 \%$ farmers who reported clinical problems with gastrointestinal nematodes (GIN), 63.6\% mentioned the occurrence of important outbreaks. Haemonchus contortus was the most common gastrointestinal parasite with mean estimated morbidity and mortality rates of $34 \%$ and $12.4 \%$, mostly involving replacement ewe lambs (70\%) on summer pastures. More severe outbreaks were reported in the eastern Pampas Region, where the $43 \%$ mean morbidity rate was higher $(P<0.033)$ than the $20 \%$ morbidity reported for the western region. Furthermore, according to $21.1 \%$ of farmers, veterinarians diagnosed mixed GIN infections presenting with diarrhea and retarded growth during the autumn-winter period in the east Pampeana region. For $80 \%$ o the farm managers GIN was a serious production problem.

Table 4 lists details of each infectious disease recorded during the survey. Enterotoxaemia occurred more frequently in replacement ewes up to one year of age. Bronchopneumonia or related respiratory clinical signs were observed in lambs (31.6\%), with high mortality, and in adults $(31.6 \%)$ without regional differences $(\mathrm{P}<0.88)$. In three outbreaks Mannheimia (Pasteurella) haemolytica was isolated.

Subcutaneous abscesses were observed in $42.1 \%$ of flocks, and $26.3 \%$ of them were diagnosed clinical or bacteriological as caseous lymphadenitis by Corynebacterium pseudotuberculosis. On one occasion Actinobacillus lignieresii was isolated from a facial abscess.

Contagious ecthyma frequently affected lambs up to three months of age. On several occasions ecthyma lesions were also observed in the teat of milking ewes.

The mean morbidity and mortality rate of clinical mastitis was $5.7 \pm 6.5$ and $2.7 \pm 4.5 \%$, respectively. Several descriptions signaled the probability of cases of gangrenous mastitis and in some farms Staphylococcus aureus was diagnosed as the cause of gangrenous mastitis. In those flocks where CMT was routinely done, a mean of $10.7 \pm 9.2 \%$ of the ewes were affected by subclinical mastitis. The percentage of owners who considered mastitis a major, medium or minor production problem were $53.8 \%, 23.1 \%$ and $23.1 \%$, respectively.

Problems of diarrhea in young stock (Table 4) were attributed to replacement milk formulas or milk excess $(50 \%)$ or to changes of forage when young animals start to eat fresh grass pastures (50\%). Escherichia coli was isolated in one outbreak of diarrhea. One case of lumpy 
Table 4. Disease prevalence in dairy sheep farms in Argentina

\begin{tabular}{lc}
\hline \multicolumn{1}{c}{ Disease prevalence } & $(\%)$ \\
\hline Enterotoxaemia & 31.6 \\
Blackleg, malignant oedema, swollen head & 5.3 \\
Tetanus & 10.5 \\
Caseous lymphadenitis & 26.3 \\
Clinical mastitis & 55.6 \\
Contagious ophthalmia & 42.1 \\
Contagious ecthyma & 73.7 \\
Ovine paratuberculosis & 5.3 \\
Pneumonia/infectious respiratory disorders & 57.9 \\
Diarrhea & 36.8 \\
Septicaemic arthritis & 15.8 \\
Foot lameness & 35.2 \\
Ewe abortions & \\
Nervous signs & 26.3 \\
Sudden death &
\end{tabular}

a Veterinary presumption of infectious etiological symptoms.

Table 5. Percentage of flocks with metabolic or deficiency diseases and other health problems in dairy sheep farms in Argentina

\begin{tabular}{lc}
\hline Farms where the disease occurs & $(\%)$ \\
\hline Pregnancy toxaemia & 10.5 \\
Rumen acidosis & 42.1 \\
Frothy bloat & 15.8 \\
Plant toxicosis & 10.5 \\
Photosensitivity & 47.4 \\
White muscle disease & 5.3 \\
Copper poisoning & 10.5 \\
Urinary calculi & 5.3 \\
Skin cancer & 26.3 \\
Chronic wasting problems & a \\
Uterine prolapse & 15.8 \\
latrogenic myositis & 31.6 \\
Traumatic accidents & 15.8 \\
Congenital and Inherited Anomalies & 36.8 \\
Predation & 26.3 \\
\hline
\end{tabular}

a Veterinary presumption of non infectious disease.

wool disease (Dermatophilus congolensis skin infection) was reported after intense rainfall periods. Cases of ewe abortions were reported (Table 4), but without an accurate diagnosis. The number of farms with abortions reported in the eastern Pampeana Region (36.4\%) was significantly higher $(\mathrm{P}<0.001)$ than those from the western Region $(12.5 \%)$. The overall mean morbidity rates of contagious ophthalmia reported was very low $(0.03 \%)$, with no significant differences between regions. In only one farm morbidity was as high as $15 \%$.

Few cases of sheep with nervous signs with very low morbidity were recorded, but in all cases without diagnosis.

The mean morbidity rate of foot lesions or lameness was $8.6 \pm 5.9 \%$ and all problems were reported in the eastern Pampeana Region. Sheep with scald or foot rot problems were only reported from the eastern Pampeana region, associated with periods of high rainfall (Wassink et al. 2003). In the dry western region in contrast, occasional foot abscesses resulting from thorn pricks, generally in the interdigital space or under the hooves were the predominant cause of lameness.

Table 5 summaries metabolic, deficiency and other health problems registered. Rumen acidosis was more frequently $(P<0.001)$ reported in the eastern region $(54.5 \%)$ than in the west $(25.0 \%)$. Only one case of milk fever (hypocalcaemia) in lactating ewes was diagnosed.

On one farm where the flock was fed indoors with concentrate rations and hay, ewes showed skin irritation with rubbing biting and itching. It seems that dust and grass spear seeds and other constraints of an indoor environment caused the problem.

Owners noticed skin cancers in adult sheep, mostly in the ears or eyelids. The more common congenital and inherited anomalies reported by the farmers were prognathism ( $21.1 \%$ of the malformations), limb deformities and arthrogryposis (15.8\%) and cryptorchidism or other external sex anomalies (5.3\%).

\section{Farmer opinions}

Farmer estimated the mean milk productive lifespan of ewes is $4.5 \pm 1.4$ years, but this was shorter $(P<0.057)$ in the eastern Pampeana Region (4.0 1.1 years) than in the western semiarid region (5.3 \pm 1.5 years).

Farmer managers ranked the most problematic diseases in the following order: GIN (40\%); mastitis (25\%), rumen acidosis (15\%), pneumonia (10\%), foot lameness $(5 \%)$ and bot fly $(2.5 \%)$.

\section{DISCUSSION}

Use of veterinary services by survey responders was high $(66.7 \%)$, and for the future of this new farm enterprise for Argentina this fact should be considered important, especially because of the high self-reported prevalence of diseases and mortality rate. Probable reasons for these findings relate to inexperience of the farm managers and their veterinarians that are not well qualified for providing advice on sheep production since cattle are more important in the centre of Argentina and get practically all the farmers attention.

Survey results show that the most important parasite problem was GIN, and in the same way this was confirmed by farmer opinions. More than half $(63.6 \%)$ farmers reported GIN outbreaks in their flocks with high mortality rates (mean of 13\%). Previous reports confirm the epidemiology and economic impact of Haemonchus contortus for meat and wool sheep production in the Pampas region (Suárez \& Busetti 1995, Suárez 2007a). Romero et al. (2007) reported that in the eastern humid of the Pampeana region $H$. contortus effects are complicated toward the winter by Trichostrongylus and Teladorsagia infection. The survey also showed that farmers treat both adult and young sheep at any time with all available anthelmintics, consequently with high risk of selection for anthelmintic resistance (Suárez 2007b).

This survey showed that biting lice are a problem for several farms, but farm managers preferred to use pour 
on biocides rather than immersion baths which would be preferable for an effective control plan (Olaechea 2007). Bot fly, of which the regional epidemiology and effects has been well described by Suárez et al. (2004), produce persistent annoyance to infected dairy ewes. However, farmers did not consider it to be a serious problem since it can be managed with avermectins or closantel. Equally, screwworm is seen as unimportant because the myiasis are easily controlled by early local insecticide application or by parenteral doramectin treatment (Suárez et al. 2000).

The prevalence of enterotoxaemia remains important, in spite of the use of clostridial vaccines in a high number of flocks $(78.9 \%)$. Clinical disease possibly occurs as a result of the fact that $33.3 \%$ of holders used vaccine only once annually, while two doses are recommended in non vaccinated young sheep, followed by annual doses. Another reason could be that some vaccines (also recommended for cattle) in Argentina have been shown to be relatively ineffective (Miranda et al. 2006).

Early bacteriological diagnoses from several farms as well as previous observations (Suárez et al. 2002) showed that Staphylococcus aureus was involved in both clinical and subclinical cases of mastitis. Results show that mastitis is a serious health and production problem, not only due to deaths and loss of udders, but also because subclinical mastitis causes substantial losses in milk yield (Miranda et al. 2001, Suárez 2004).

Serious respiratory clinical diseases were one of the major problems noticed by farmers who reported depression, fever, emaciation, difficulty in breathing and sometimes coughing. Unfortunately, commercial vaccines have not been very effective (Cassirer et al. 2001, Alley 2002). Maedi-Visna is a frequent disease of dairy sheep flocks of Europe and other regions (Pepin et al. 1998), but in Argentina is rare as confirmed this survey with negative results. However, only $21.1 \%$ of the farmers sampled their animals for Maedi-Visna test.

The prevalence of caseous lymphadenitis registered could be underestimated in several farms, because cases of progressive emaciation of ewes and multiple internal abscesses at necropsy described by farmers could be associated with $C$. pseudotuberculosis. Vaccines are apparently beneficial (Hodgson et al. 1999), but are not available in Argentina. Arthritis in lambs and adults rams was described by owners (15.8\%) associated with swollen and enlarged knee or other leg joints (Kaferstein et al. 1972), but the responsible microorganisms were not determined.

Since milk sheep breeds such as East Friesian and Pampinta are prolific, farmers know that they must be wary of metabolic disorders in these breeds. A variety of other problems such as forage reserves and rent high prices often lead to small land forage surface and high stoking rates that induce starvation, pregnancy toxaemia, chronic wasting diseases, and downer syndromes. Likewise, frequent cases of uterine prolapse $(31.6 \%)$ or dystocia may have resulted from poor sheep condition during winter before lambing.

The frequent cases of rumen acidosis $(42.1 \%)$ reported mostly in the eastern region were attributed to farmers inexperience, especially at the start of concentrate feeding.

Plant toxicosis, including Baccharis coridifolia and Cestrum parqui poisoning, were frequently observed, especially when newly purchased animals were first introduced to the farms. Death from copper poisoning were also reported (Table 5), usually from drinking copper sulphate footbath fluid or when sheep were fed with bovine copper supplements.

Photosensitivity (47.4\%) was frequently reported, accompanied by swollen ears as well as other exposed facial areas. The cause was not determined, but lesions were more common from late spring when photodynamic agents from some plants induced sensitivity to sunlight.

The possibility of a genetic predisposition to squamous cell carcinomas should be considered in flocks with high ewe morbidity rate, as well as other predisposed factors like solar injury or photosensitivity incidence. This pathology is very uncommon in wool and meat sheep breeds of this region (Suárez, unpublished data).

latrogenic myositis and trauma are more frequently reported in young sheep than in adult ewes and are often caused by carelessness with vaccination or other management practices. In addition, losses arising from theft $(21.1 \%)$ and predation by dogs $(31.6 \%)$ was a problem on farms situated close to towns.

Mean perinatal mortality (8.5\%) was not very high, but ranged from zero in an intensive farm system to more that $25 \%$ in an extensive system, which is high in comparison to other sheep systems (Suárez et al. 1990). East Friesian and Pampinta are prolific breeds with lambing rate of more than $200 \%$ (Suárez et al. 1998) and precautions should be taken during lambing to avoid deaths in multiple births. In some instances perinatal deaths were caused by poor pre-lambing condition of ewes but on other farms predators such as Polyborus plancus or Chaetophractus villosus were identified as important causes.

Pre and post-weaning lamb mortality (respectively $10.3 \%$ and $5.9 \%$, excluding perinatal mortality) were high and seems to result from environmental factors such us overcrowding and poor hygienic measures during the first few months of life, and from deficient post-weaning GIN control measures. Previous trials of Suárez (1985) showed 3/4 East Friesian $\mathrm{x}$ Corriedale crossbreed dairy sheep to be less resistant than Corriedale to GIN infection. In addition, differences between the total flock mortality rates and ewe production lifespan in the eastern and western survey regions could be partially due to differences in the prevalence of GIN and foot lameness. Moreover, regarding sheep breed origin of dairy ewes in Argentina, producers should be warned about the short lifespan of East Friesian breed and crosses of over $50 \%$, reported from several countries to be less than three years, with high prevalence of pneumonia (Ricordeau \& Flamand 1969, Thomas et al. 1999). 
While farmers in the eastern Pampeana region regarded GIN (58.3\%), mastitis (16.7\%), footrot $(8.3 \%)$, pneumonia $(8.3 \%)$, and acidosis $(8.3 \%)$ as the most important, those in the western region were of the opinion that their most important problems were the respiratory disorders (26.7\%), rumen acidosis (20\%) and GIN (13.3\%). Although, these are subjective opinions, they correlate quite well with the results of this survey.

This investigation provides an indication of the prevalence and the possible impact of diseases in the new sheep dairy milk systems of Argentina. The high rates of lamb mortality as well as the most prevalent diseases that shorter the productive lifespan of the ewes should be studied to improve these constrains on production. Moreover in the future, post-graduate courses should be implemented in dairy sheep health to resolve current deficiencies in veterinary knowledge qualification.

Acknowledgements.- We are grateful to the owners and their families for their participation and cooperation during the survey. We specially wish to thank Dr. Jan van Wyk and Mark Stevenson for corrections to the manuscript.

\section{REFERENCES}

Alley M.R. 2002. Pneumonia in sheep in New Zealand: An overview. N. Z. Vet. J. 50: 99-101.

Cassirer E.F., Rudolph K.M., Fowler P., Coggins V.L., Hunter D.L. \& Miller M.W. 2001. Evaluation of ewe vaccination as a tool for increasing bighorn lamb survival following pasteurellosis epizootics. J. Wildl. Dis. 37:49-57.

Hodgson A.L.M., Carter K., Tachedjian M., Krywult J., Corner L.A., Mccoll M. \& Cameron A. 1999. Efficacy of an ovine caseous lymphadenitis vaccine formulated using a genetically inactive form of the Corynebacterium pseudotuberculosis phospholipase D. Vaccine 17:802-808.

Kaferstein F.K., Ekdahl M.O. \& Almand K. 1972. The importance of ovine arthritis in meat hygiene in New Zealand. N. Z. Vet. J. 20:49-53.

Miranda A.O., Suarez V.H., Calvinho L., Busetti M.R., Canavesio V. \& Bedotti D.O. 2001. Epidemiología de las mastitis subclínicas en ovejas lecheras en la región pampeana. Vet. Arg. 18(176):411-422.

Miranda A., Fort M.C., Cerviño M. \& Carloni G. 2006. Evaluación de la respuesta serológica de vacunas comerciales frente a Clostridium Chauvoei. Vet. Arg. 23(221):20-26.

Olaechea F.V. 2007. Phthiriasis y melofagosis, p.205-216. In: Suarez V.H., Olaechea F.V., Rossanigo C.E. \& Romero J.R. (Eds), Enfermedades Parasitarias de los Ovinos y Otros Rumiantes Menores en el Cono Sur de América. Ediciones INTA PT.70, Anguil, Argentina.

Pepin M., Vatu C., Russo P., Mornex J.F. \& Peterhans E. 1998. MaediVisna virus infection in sheep: A review. Vet. Res. 29:341-367.

Ricordeau G. \& Flamand J.C. 1969. Croisements entre les races ovines Prealpes du Sud et Frisonne (Ostfriessisches Milchschaf). II. Reproduction, viabilité, croissance, conformation. Ann. Zootech. 18:131-149.

Romero J.R., Sánchez R.O. \& Boero C.A. 2007. Epidemiología de las gastroenteritis verminosa de los ovinos en la pampa húmeda y la
Mesopotamia, p.33-42. In: Suarez V.H., Olaechea F.V., Rossanigo C.E. \&Romero J.R. (Eds), Enfermedades Parasitarias de los Ovinos y Otros Rumiantes Menores en el Cono Sur de América. Ediciones INTA PT.70, Anguil, Argentina.

Suárez V.H. 1985. Comparación del efecto de la parasitosis gastrointestinal sobre 2 razas ovinas 3/4 Ost Friesian x 1/4 Corriedale y Corriedale en la Región Semiárida Pampeana. Vet. Arg. 2(16):554561.

Suárez V.H. 2004. Lechería ovina y Raza Pampinta. Revta IDIA 21(7):194-200.

Suárez V.H. 2007a. Epidemiología y control de los nematodes gastrointestinales en el oeste de la Región Pampeada, p.43-62. In: Suarez V.H., Olaechea F.V., Rossanigo C.E. \& Romero J.R. (Eds), Enfermedades Parasitarias de los Ovinos y Otros Rumiantes Menores en el Cono Sur de América. Ediciones INTA PT.70, Anguil, Argentina.

Suárez V.H. 2007b. Resistencia antihelmíntica en nematodes ovinos, p.85-106. In: Suarez V.H., Olaechea F.V., Rossanigo C.E. \& Romero J.R. (Eds), Enfermedades parasitarias de los ovinos y otros rumiantes menores en el Cono Sur de América. Ediciones INTA PT.70, Anguil, Argentina.

Suárez V.H., Fort M.C., Busetti M.R \& Bedotti D.O. 1990. Niveles de producción de una majada Corriedale que pastorea pasto llorón, Eragrostis curvula (Schrad) Nees. Revta Arg. Prod. Anim. 10 (2): 161168

Suárez V.H. \& Busetti M.R. 1995. Epidemiology of helminth infections of growing sheep in Argentina's Western Pampas. Int. J. Parasitol. 25:489-494.

Suárez V.H., Busetti M.R., Ortellado Real M.R., Babinec F.J., Garriz C.A, Silva Colomer J. \& Talmon G.D. 1998. Características productivas de la raza ovina Pampinta. Therios 27:195-203.

Suárez V.H., Nari A., Cardoso H., Moltedo H.C. \& Derozier C. 2000. Prophylactic efficacy of doramectin against screw worm (Cochliomyia hominivorax) strikes in sheep in Latin America. Resúmenes XXI Congreso Mundial de Buiatría, Punta del Este, Uruguay, p.164.

Suárez V.H., Busetti M.R., Miranda A.O., Calvinho L., Bedotti D.O. \& Canavesio V. 2002. Effects of infectious status and parity on somatic cell count and California mastitis test in Pampinta dairy ewes. J. Vet. Med. B 49:230-234.

Suárez V.H., Busetti M.R., Miranda A.O. Prevot \& F., Jacquiet P.H. 2004. Epidemiology of Oestrus ovis infection of sheep in Argentina's Western Pampas. Parasite 11(4):405-410.

Thomas D.L., Berger Y.M. \& McKusik B.C. 1999. East Friesian germoplasm: Effects on milk production, lamb growth and lamb survival. Proc. American Society of Animal Science, Indianapolis, Indiana, USA. Online. Website http://www.asas.org/jas /symposia/ proceedings/0908. pdf.

Thomas D.L. 2004. Overview of the dairy sheep sector in Canada and United States, p.6-14. In: $10^{\text {th }}$ Great Lakes Dairy Sheep Symposium, Hudson, Wisconsin. Department of Animal Science, University of Wisconsin-Madison, USA.

Thrusfield M. 1997. Veterinary Epidemiology. $2^{\text {nd }}$ ed. Blackwell Science, London. 483p.

Wassink G.J., Grogono-Thomas R., Moore L.J. \& Green L.E. 2003. Risk factors associated with the prevalence of footrot in sheep from 19992000. Vet. Rec. 154:551-555.

Wayne M.S., Meek A.H. \& Willeberg P. 1987. Veterinary Epidemiology: Principles and methods. lowa State University Press, Ames. 343p. 